\title{
Examination of Population Information System as the E-Government Development in Regency
}

\author{
Ferdiansyah, Phong Thanh Nguyen, N. Sharmili, K. Shankar, Satria Abadi, Wahidah Hashim, \\ Andino Maseleno
}

\begin{abstract}
The government established policies regarding population administration based on Law No. 23 of 2006 concerning Population Administration. To implement registration in the field of civil registration, the government launched a population administration information system (Bahasa: Sistem Informasi Administrasi Kependudukan (SIAK)) to obtain and manage easily the population data. Thus, it needed a study to identify potential problems that arised from the provisions in the registration of SIAK-based civil registration that aims to facilitate the community in making SIAK and early identification of problems in the process of population registration in the field of civil registration such in Tanggamus Regency, there were still many problems in the field of civil registration. From this problem, the writer conducted research regarding how the rules to make SIAK so that e-government is served in the field of civil registration, and how the process of population registration in the field of civil registration and what were the obstacles encountered in the implementation and how to overcome it, while the data analysis was done qualitatively. Based on research data conducted in the Tanggamus Regency Government, the results obtained were that SIAK Regulations in Tanggamus Regency regulated in local regulation No.12 of 2008 concerning the Implementation of Population Administration which is adjusted in Constitution No.23 of 2006 concerning Administration, although in implementation regulations issued were still experiencing problems. However, these obstacles were overcome by efforts such as social approaches and improving services to the people of Tanggamus Regency.
\end{abstract}

Keywords : Population Information System Design (SIAK), E-government development.

\section{INTRODUCTION}

The Republic of Indonesia government through the Ministry of Home Affairs is currently implementing an e-KTP program based on the Population Registration

Revised Manuscript Received on July 22, 2019.

* Correspondence Author

Ferdiansyah, Department of Information Systems, STMIK Pringsewu, Lampung, Indonesia.

Phong Thanh Nguyen*, Department of Project Management, Ho Chi Minh City Open University, Vietnam. E-mail: phong.nt@ou.edu.vn

N. Sharmili, Associate Professor, Department of Computer Science Engineering, Vignan's Institute of Information Technology for Women, Andhra Pradesh, India.

K. Shankar, Department of Computer Applications, Alagappa University, Karaikudi, India. E-mail: shankarcrypto@gmail.com

Satria Abadi, Department of Information Systems, STMIK Pringsewu, Lampung, Indonesia.

Wahidah Hashim, Institute of Informatics and Computing Energy, Universiti Tenaga Nasional, Malaysia.

Andino Maseleno, Institute of Informatics and Computing Energy, Universiti Tenaga Nasional, Malaysia.
Number (NIK) as an implementation of constitution No. 23 of 2006 concerning Population Administration. To support the effectiveness and efficiency of the program, the government developed the Population Administration Information System (SIAK) for the respective districts in Tanggamus. In the development of SIAK, it has been socialized through an order from the Regent of each district that has been socialized through local government in the District since 2004 with the launch of SIAK online from the District to the data center. It then followed by SIAK offline in the Regency / City in 2005. The SIAK system design provides population registration and civil registration services in Tanggamus Regency which are then designed through each Sub-District in Tanggamus District, which directly connected to the data center of the Directorate General of Population Administration (DG Adminduk) via VPN dial. The latest SIAK grand design improvement result were agreed by the Technical Team from 15 Ministries/Institutions on August 4, 2010 and had been determined by the Minister of Home Affairs Decree on August 13, 2010.

Meanwhile, the results of hardware improvement, software, and e-KTP blank specifications were agreed by the Technical Team on December 28, 2010 and determined by domestic government regulation No. 6 of 2011. By the end of 2012, it was targeted that SIAK in 497 districts / cities will be connected online with the central and provincial levels, and SIAK services of 6.589 sub-districts and 497 districts/cities will be connected (online) to district /cities, central and provinces. At the end of 2013, SIAK in the Ministry of Home Affairs and regions was targeted to be connected online with user agencies gradually. Information and publications related to e-KTP, NIK, population database, system integration and other related aspects were discovered. However, related to population database utilization in the variety of information system applications in the district/city government (Regency / City Government) is still minimal.

Protection in strengthening the each population domicile constitutes guarantees, protections, and legal certainty for everyone. The Government needs to establish a Population Law concerning residence eligibility that is non-discriminatory. Therefore, a comprehensive and systematic arrangement is needed to become a guideline for state and community administrators in the area of population that is detailed and

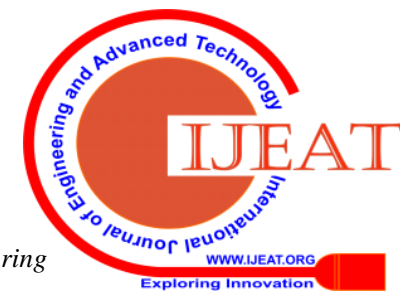


accurate in the data collection. Thus, the Government established Law Number 23 of 2006 concerning Population Administration. The implementation of Occupational Administration can only be carried out if it is supported by professional services such the Implementing Agency of the regional government in the Department of Population and Civil Registration and increasing the awareness of the population by the community including Indonesian citizens who are abroad. In Law No.23 of 2006, one of them regulates Civil Registration. The implementation is carried out by registering and recording the number of occupants and assessing the number of migrants and legal domiciles in the district.

To get recognition, guarantees, protection, and legal certainty for everyone, the Government needs to establish a law that is not discriminatory. Thus a comprehensive and systematic arrangement is needed to become a guide for state and community organizers in the population sector. For this reason, the Government established Law Number 23 of 2006 concerning Population Administration. The implementation of Population Administration can only be carried out if it is supported by professional services such the Implementing Agency of the Population and Civil Registration department and increasing the awareness of the population including Indonesian citizens who are abroad. In Law No.23 of 2006, one of them regulates Civil Registration which is carried out by Population Registration in which to count the population, it collects data on important events such as birth, death, marriage, divorce, child recognition, etc. In government organizations, public service is the main goal that can not be avoided because it is an obligation to carry out services by creating the best service for the public. It has become an obligation, so the government should find the best solution to solve the problems that are often faced, including internal obstacles that originate from within the agency itself and external obstacles that come from public related to the public services they handle. In addition, employees must always provide the best service for public as a whole. The level of public satisfaction is an important indicator for the success of public services where the greater benefits perceived by the public indicates the better service quality carried out by the apparatus. Meanwhile, the low satisfaction level indicates the poor service system of the public apparatus.

(http://silahudin66.blogspot.com/2010/05/standa rd-pelayanan-publik.html)

One of the worrying public services quality is the quality of Department of Population and Civil Registry as a provider of birth certificates. Broadly speaking, ownership of birth certificates is very important. It is as explained about the rights of children in various 1945 Constitution which contained in article 28 B paragraph 2, namely "Every Child is entitled to Survival, Growth and Development, and protected from violence and discrimination"

(http://gunawanharo.blogspot.com/2011/11/makalah-metho d-research-administration.html).

\section{RESEARCH METHODOLOGY}

To deal with this research, the author used a quantitative approach to process data obtained from the study sitework. Quantitative data, according to Sugiyono (2006: 14), is data in the form of numbers or qualitative data that is compiled. Quantitative approach is the search of factual data / information realted to the problems which directed to prove the concept/theory used. The type of research used was a descriptive type to provide a clear picture of the problems in the research by observing, interpreting and explaining the data systematically. The basis of this research was the survey by distributing questionnaires to the respondents containing questions about matters relating to research.

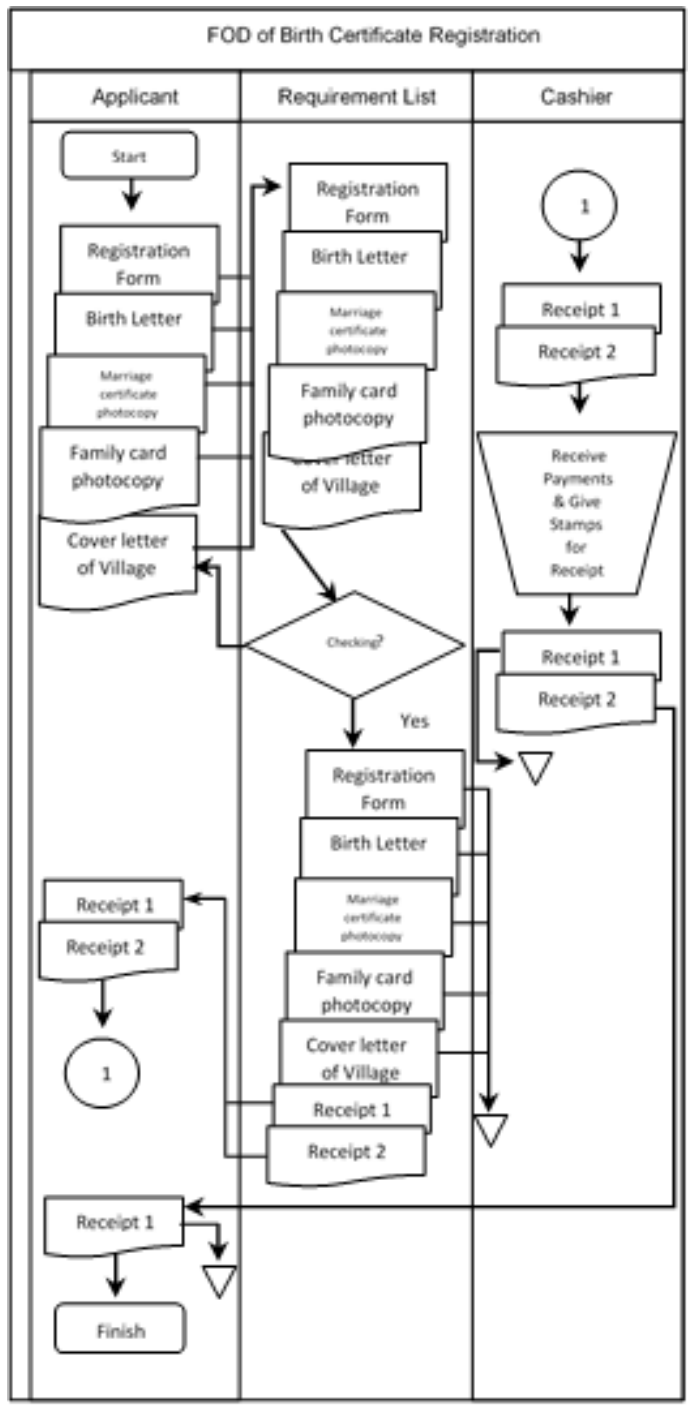

Figure 1: FOD Birth Certificate Registration

The purpose of this population administration information system is to realize population administration services and civil registration oriented to the satisfaction and public cooperation to create the accurate population data and information. This system is also expected to create good governance. It can also provide convenience services from an agency to carry out processes related to population problems and make it easy for the community to have the population registration process. 


\section{RESEARCH RESULTS}

\subsection{Population Data (SIAK)}

Referring to domestic government regulation (Permendagri) No. 25 of 2011 concerning Guidelines for Assessment, Development and Management of Population Administration Information Systems, the population database of SIAK has a complex and uniform content. Specifically, the population database center uses a very large database platform that contains regional data; family; biodata; civil registration; and photos, fingerprints, and signatures. Regional data consists of name and province code, district/city name and code, district/other names and codes, and names and codes of villages. Meanwhile, family data consists of family card number, family name, address, RT and RW, Post code; and telephone number (Table 1). Referring to Law no. 23 of 2006, every citizen is required to have a NIK, is valid for life, and is included in every Population Document and is used as the basis for the issuance of a passport, driver's license, NPWP, insurance policy, land certificate, and others. NIK is given to every baby born reported by parents who are registered as residents of an area and registered as one family, in 16-digit format, namely [Law No. 52 of 2009]:

\begin{tabular}{|c|c|}
\hline $\sin 10$ & Grin \\
\hline Bode WW & 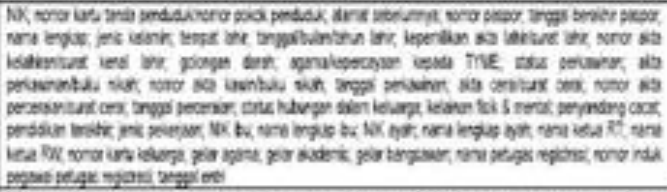 \\
\hline Bexamysac; & 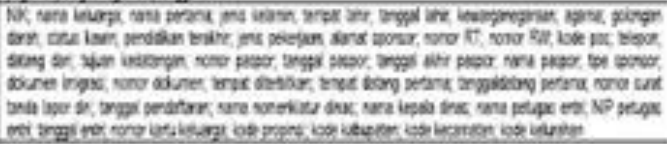 \\
\hline $\begin{array}{l}\text { Defersin od } \\
\text { leatur }\end{array}$ & 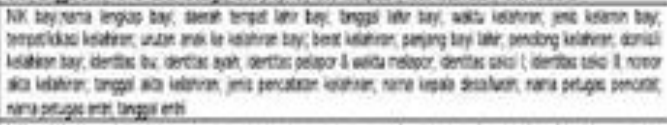 \\
\hline 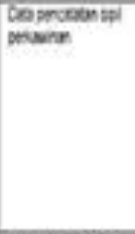 & 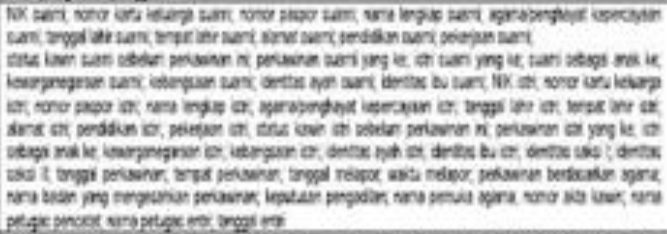 \\
\hline 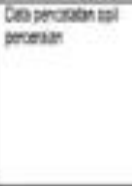 & 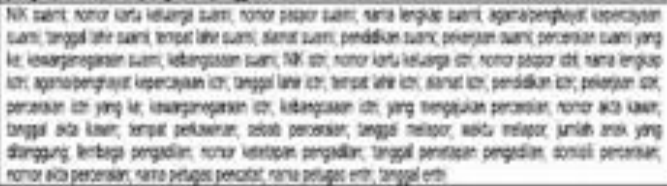 \\
\hline $\begin{array}{l}\text { Cenperciton ail } \\
\text { ieter }\end{array}$ & 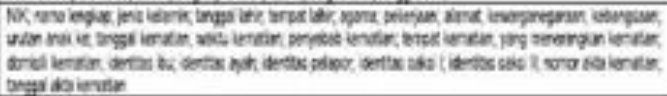 \\
\hline $\begin{array}{l}\text { Cespranen:ai } \\
\text { pevservs }\end{array}$ &  \\
\hline 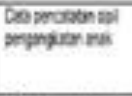 & 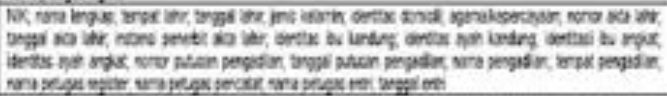 \\
\hline 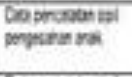 & 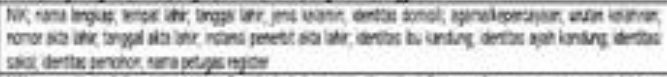 \\
\hline 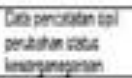 & 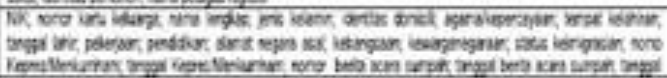 \\
\hline
\end{tabular}

3.1 Population data items for each type of data in SIAK

\begin{tabular}{|c|c|c|c|}
\hline No & Actor & Event & Respon \\
\hline 1 & Operator & Registrasi & Informasi tentang registrasi operator \\
\hline 2 & Operator & Validasi Id & $\begin{array}{l}\text { Pengaktifan sistem dengan memasukan id } \\
\text { pengguna yang valid }\end{array}$ \\
\hline 3 & Operator & Invalid Id & $\begin{array}{l}\text { Jika id invalid maka sistem akan } \\
\text { menampilkan pesan tersebut }\end{array}$ \\
\hline 4 & Operator & Fitur & Pilihan fitur sistem yang akan dipakai \\
\hline 5 & Operator & $\begin{array}{l}\text { Pengolahan Data } \\
\text { KK }\end{array}$ & Input, edit, hapus, cetak data \\
\hline 6 & Operator & $\begin{array}{l}\text { Pengolahan Data } \\
\text { KTP }\end{array}$ & Input, edit, hapus, cetak data \\
\hline 7 & Operator & $\begin{array}{l}\text { Pengolahan Data } \\
\text { Akta lahir }\end{array}$ & Input, edit, hapus, cetak data \\
\hline 8 & Operator & $\begin{array}{l}\text { Pengolahan Data } \\
\text { Pindah Penduduk }\end{array}$ & Input, edit, hapus, cetak data \\
\hline 9 & Operator & $\begin{array}{l}\text { Pengolahan Data } \\
\text { Penduduk } \\
\text { Meninggal }\end{array}$ & Input, edit, hapus, cetak data \\
\hline
\end{tabular}

3.2 Data involved in the SIAK system

The effort to develop the Population Administration Information System is a very urgent need, especially to fulfill the rights of the population and social protection by having transparent, orderly, satisfying and affordable services for public.

\section{DISCUSSION}

The Tanggamus Regency Government in this matter through the Ministry of Home Affairs is currently implementing an e-KTP program based on the National Population Number (NIK) as the implementation of Law No. 23 of 2006 concerning Population Administration. Referring this law, the Ministry of Home Affairs has the obligation and responsibility to carry out population administration nationally. The Provincial Government is obliged and responsible to execute the population administration at the provincial scale. Meanwhile, regency/City Government is obliged and responsible to have population administration at the Regency/City Scale conducted by the Regent/Mayor. The Regency/City Dukcapil Agency is obliged to provide population registration and civil registration services, and issue population documents. The NIK-based e-KTP program aims to obtain an orderly database and orderly population documents [Ministry of Home Affairs, 2011]. The e-KTP program was issued based on the Law No. 23 of 2006, Presidential Regulation (Perpres) No. 26 of 2009, and Perpres No. 35 of 2010. Thus, it applies nationally and make the public easier to get services from Government and private institutions, because they no longer need a local ID card. Related to this program, the Government is currently in the stage of recording fingerprints, photographs and signatures, and there are still 3 stages that must be implemented, namely e-KTP personalization, e-KTP issuance, and e-KTP submission. To support the effectiveness and efficiency of NIK issuance and the application of e-KTP, the government developed the Population Administration Information System (SIAK). The Center for Information and Communication

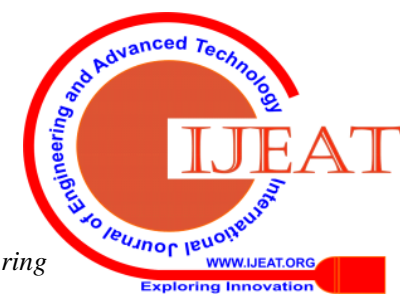


Technology (PTIK) BPPT assists the Ministry of Home Affairs in technical development of online SIAK software that includes the design of inter-district network infrastructure, the data center at the Directorate General of Population Administration, the design of disaster recovery center (DRC), the consolidation of data in the system, and providing assistance technique in making e-KTP. Based on the phenomena that have been stated in the background above, the formulation of the problem in this study is as follows: How high is the Birth Certificate services quality of population and Civil Registry department of Tanggamus Regency that runs on Disdukcapil so far have used computerization. The data processing and manufacturing process also used a system that had been provided by the Ministry of Home Affairs. So that the manufacturing process did not experience too many obstacles. Problems will arise if the public service is less and there is no best solution. The manual birth certificate registration service sometimes faces a human error such the error entry number. This has a problem in the manufacturing process, moreover the wrong deed is taken due to lack of information on the receipt. If it is implemented by using a computerized system, the performance of Dukcacil department under Civil Registration is expected to increase. Therefore, a registration application and birth certificate service will be made to resolve problems that were previously resolved manually.

\section{CONCLUSION}

By the creation of SIAK Based on the description above, it is necessary to have a commitment to the develop e-Government that change the manual work culture into electronic by utilizing information technology tools. This is in line with the main goal of e-government, which is to improve the quality of service for the community. By e-Government, it expect to become one of the new breakthrough alternatives in providing better public services and to be a strategic information resource that is very helpful for the community to process the birth certificates and advance Tanggamus Regency to be even more recorded population.

The development of SIAK as one form of e-government development, then:

a. The establishment of SIAK aims to support "good governance" as a necessity especially to support the population process in Tanggamus Regency.

b. Many things were obtained from the development of SIAK, such as, to realize population management services and the population have been recorded in the civil records oriented to have the accurate data and public cooperation to create accurate population data and information, this system is also expected to improve the society condition.

In processing the SIAK, there are several advantages, that expects to develop after the creation of SIAK, those are:

a. Provide fast public information to create population documents.

b. Accelerate the processing of population documents such as making KTP, family cards and other letters.

Based on the description above, It needs a commitment to develop the e-Government and change the manual work culture into electronic by utilizing information technology devices. This is in line with the main goal of e-Government,

which is to improve the quality of service for the community, By utilizing the e-Government, it expects to become one of the new breakthrough alternatives in providing better public services and to be a strategic information resource.

The advantages that are expected to develop by implementing SIAK are:

- Provide fast public information to process the population documents.

- Accelerate the processing of population documents such as the making of ID cards, family cards and other letters.

- Creating a correct, fast and accurate population administration.

- Achieving a satisfied population administration services and civil registration and public cooperation to create accurate population data and information.

\section{REFERENCES}

1. Chienwattanasook, K., Wattanapongphasuk, W., Prianto, A., \& Jermsittiparsert, K. 2019. "Corporate Entrepreneurship and Business Performance of Logistic Companies in Indonesia." Industrial Engineering \& Management Systems 18 (3): 538-547.

2. Dawabsheh, M., Hussein, A., \& Jermsittiparsert, K. 2019. "The Triangular Relationship between TQM, Organizational Excellence and Organizational Performance: A Case of Arab American University Palestine.” Management Science Letters 9 (6): 921-932.

3. Jermsittiparsert, K., Siam, M., Issa, M., Ahmed, U., \& Pahi, M. 2019. "Do Consumers Expect Companies to Be Socially Responsible? The Impact of Corporate Social Responsibility on Buying Behavior." Uncertain Supply Chain Management 7 (4): 741-752.

4. Syazali, M., Putra, F., Rinaldi, A., Utami, L., Widayanti, Umam, R., \& Jermsittiparsert, K. 2019. "Partial Correlation Analysis Using Multiple Linear Regression: Impact on Business Environment of Digital Marketing Interest in the Era of Industrial Revolution 4.0." Management Science Letters 9 (11): 1875-1886.

5. Sae-Lim, P. \& Jermsittiparsert, K. 2019. "Is the Fourth Industrial Revolution a Panacea? Risks toward the Fourth Industrial Revolution: Evidence in the Thai Economy." International Journal of Innovation, Creativity and Change 5 (2): 732-752.

6. Chatchawanchanchanakij, P., Arpornpisal, C., \& Jermsittiparsert, K 2019. "The Role of Corporate Governance in Creating a Capable Supply Chain: A Case of Indonesian Tin Industry." International Journal of Supply Chain Management 8 (3): 854-864.

7. Hartinah, S., Suharso, P., Umam, R., Syazali, M., Lestari, B., Roslina, R., \& Jermsittiparsert, K. 2020. "Teacher's Performance Management: The Role of Principal's Leadership, Work Environment and Motivation in Tegal City, Indonesia.” Management Science Letters 10 (1): 235-246.

8. Haseeb, M., Hussain, H., Slusarczyk, B., \& Jermsittiparsert, K. 2019. "Industry 4.0: A Solution towards Technology Challenges of Sustainable Business Performance.” Social Sciences 8 (5): 184.

9. Haseeb, M., Hussain, H., Kot, S., Androniceanu, A., \& Jermsittiparsert, K. 2019. "Role of Social and Technological Challenges in Achieving a Sustainable Competitive Advantage and Sustainable Business Performance.” Sustainability 11 (14): 3811.

10. Haseeb, M., Kot, S., Hussain, H., \& Jermsittiparsert, K. 2019. "Impact of Economic Growth, Environmental Pollution, and Energy Consumption on Health Expenditure and R and D Expenditure of ASEAN Countries." Energies 12 (19): 3598.

11. Huda, S., Tsani, I., Syazali, M., Umam, R., \& Jermsittiparsert, K. 2020. "The Management of Educational System Using Three Law Auguste Comte: A Case of Islamic Schools.” Management Science Letters 10 (3) (In press), DOI: 10.5267/j.msl.2019.9.018.

12. Usak, M., Kubiatko, M., Shabbir, M., Dudnik, O., Jermsittiparsert, K., \& Rajabion, L. 2019. "Health Care Service Delivery Based on the Internet of Things: A Systematic and Comprehensive Study." International Journal of Communication Systems 32 (14): e4179.

13. Jermsittiparsert, K., Ambarita, D., Mihardjo, L., \& Ghani, E. 2019. "Risk-Return through Financial Ratios as Determinants of Stock Price: A Study from ASEAN Region." Journal of Security and Sustainability Issues 9 (1): 199-210. 
14. Thabhiranrak, T. \& Jermsittiparsert, K. 2019. "Towards Sustainable Functioning of Organization: Women Empowernment and Corporate Management Culture." Journal of Security and Sustainability Issues 9 (1): 321-332.

15. Maseleno, A., Hardaker, G., Sabani, N., \& Suhaili, N. (2016). Data on multicultural education and diagnostic information profiling: Culture, learning styles and creativity. Data in brief, 9, 1048.

16. Maseleno, A., Huda, M., Jasmi, K. A., Basiron, B., Mustari, I., Don, A G., \& bin Ahmad, R. (2019). Hau-Kashyap approach for student's level of expertise. Egyptian Informatics Journal, 20(1), 27-32.

17. Maseleno, A., Huda, M., Siregar, M., Ahmad, R., Hehsan, A., Haron, Z., ... \& Jasmi, K. A. (2017). Combining the previous measure of evidence to educational entrance examination. Journal of Artificial Intelligence, 10(3), 85-90.

18. Chienwattanasook, K. \& Jermsittiparsert, K. 2019. "Impact of Entrepreneur Education on Entrepreneurial Self-Employment: A Case Study from Thailand." Polish Journal of Management Studies 19 (1): 106-116.

19. Jermsittiparsert, K., Sutduean, J., Sriyakul, T., \& Khumboon, R. 2019. "The Role of Customer Responsiveness in Improving the External Performance of an Agile Supply Chain." Polish Journal of Management Studies 19 (2): 206-217.

20. Jermsittiparsert, K., Sutduean, J., \& Sriyakul, T. 2019. "Effect of Service Innovation and Market Intelligence on Supply Chain Performance in Indonesian Fishing Industry." Industrial Engineering \& Management Systems 18 (3): 408-417.

21. Jermsittiparsert, K., Namdej, P., \& Somjai, S. 2019. "Green Supply Chain Practices and Sustainable Performance: Moderating Role of Total Quality Management Practices in Electronic Industry of Thailand." International Journal of Supply Chain Management 8 (3): $33-46$.

22. Somjai, S. \& Jermsittiparsert, K. 2019. "The Trade-off between Cost and Environmental Performance in the Presence of Sustainable Supply Chain." International Journal of Supply Chain Management 8 (4): 237-247.

23. Jermsittiparsert, K. \& Sawasdee, A. 2012. "Formal Education for Non-Thai or Undocumented Person in Thailand amidst the Challenge of Nationalism and Transnationalism: A Case Study of Wat Sirimongkhol School, Samut Sakhon Province." Kasetsart Journal - Social Sciences 33 (2): 203-213. 